\title{
MENINGKATKAN RASA PERCAYA DIRI ANAK MELALUI TERAPI BERMAIN
}

\author{
Diana Ariswanti Triningtyas *)
}

\begin{abstract}
Abstrak
Usia prasekolah anak diharapkan menguasai belajar menulis, bahasa, matematika dan ilmu pengetahuan lain. Pengetahuan akan konsep ini jauh lebih mudah diperoleh melalui kegiatan bermain. Anak usia prasekolah mempunyai rentang perhatian yang terbatas dan masih sulit diatur, apalagi belajar dengan "serius". Tetapi bila pengalaman konsep tersebut dilakukan sambil bermain, membuat anak senang, tanpa disadari ternyata ia sudah banyak belajar. Aspek perkembangan anak dapat ditumbuhkan secara optimal dan maksimal melalui kegiatan bermain. Saat bermain, anak-anak mempelajari banyak hal penting.

Adapun jumlah anak yang diteliti adalah 23 anak. Penelitian ini bertujuan untuk mengetahui peningkatan rasa percaya diri anak melalui terapi bermain. Untuk mencapai tujuan tersebut, maka dalam penelitian menggunakan metode observasi, wawancara, dan analisis data.

Dinyatakan meningkat jika rata-rata prosentase masing-masing indikator yang dimiliki lebih atau sama dengan $75 \%$. Sebaliknya percaya diri anak dinyatakan belum meningkat jika rata-rata prosentase masing-masing indikator kurang dari $75 \%$. Hasil penelitian menunjukkan bahwa adanya peningkatan yang baik dari Siklus I dan Siklus II mencapai $80 \%$. Hal ini menunjukkan bahwa terapi bermain tepat untuk diterapkan pada anak karena mudah dipahami dan disukai anak.
\end{abstract}

Kata Kunci: Terapi Bermain, Rasa Percaya Diri Anak.

* Diana Ariswanti Triningtyas adalah Dosen Program Studi Bimbingan dan Konseling Fakultas Ilmu Pendidikan IKIP PGRI Madiun. 


\section{Pendahuluan}

Sekarang ini, tuntutan orang tua dan masyarakat terhadap prestasi anak didik yang terus meningkat dalam bidang akademik, menyebabkan sekolah dengan segala daya upaya mencoba memenuhi tuntutan tersebut dengan berbagai kegiatan yang cenderung akademis. Waktu mereka untuk bermain dan bersosialisasi dengan teman sebaya tidak ada lagi. Padahal sudah sangat banyak ahli pendidikan dan psikologi yang mengingatkan bahwa perkembangan seorang anak tidak hanya diukur dari sisi intelektualnya saja tetapi juga perkembangan aspek-aspek fisik, moral, sosial, kultural, dan emosionalnya.

Anak usia prasekolah diharapkan menguasai belajar menulis, bahasa, matematika dan ilmu pengetahuan lain. Pengetahuan akan konsep ini jauh lebih mudah diperoleh melalui kegiatan bermain. Anak usia prasekolah mempunyai rentang perhatian yang terbatas dan masih sulit diatur, apalagi belajar dengan “serius". Tetapi bila pengalaman konsep tersebut dilakukan sambil bermain, membuat anak senang, tanpa disadari ternyata ia sudah banyak belajar. Melalui kegiatan bermain, semua aspek perkembangan anak ditumbuhkan sehingga anakanak menjadi lebih sehat sekaligus cerdas. Aspek perkembangan anak dapat ditumbuhkan secara optimal dan maksimal melalui kegiatan bermain. Saat bermain, anak-anak mempelajari banyak hal penting.

Setiap anak memiliki potensi, dan potensi yang dimiliki setiap anak berbeda-beda secara kualitas maupun kuantitas. Potensi diri adalah kemampuan dan kekuatan yang dimiliki oleh anak baik fisik maupun mental dan mempunyai kemungkinan untuk dikembangkan bila dilatih dan ditunjang dengan sarana yang baik, sedangkan diri adalah seperangkat proses atau ciri-ciri proses fisik perilaku dan psikologis yang dimiliki (Sri Habsari, 2005).

Potensi anak dapat dikembangkan apabila anak mempunyai rasa percaya diri. Menurut Akrin Ridho (dalam Izzatul Jannah, 2002) menyatakan bahwa, "Kepercayaan pada diri sendiri adalah sumber potensi utama seseorang dalam hidupnya". Rasa percaya diri sangatlah diperlukan oleh setiap anak, terutama anak usia prasekolah. Tanpa rasa percaya diri anak akan berperilaku kikuk bahkan aneh. Misal, ketika anak sedang melakukan kegiatan menyanyi, menari, berpidato, 
dan sebagainya tanpa dilandasi rasa percaya diri pastilah hasilnya tidak akan memuaskan. Hal ini akan menjadi hambatan dalam mengembangkan potensi yang ada dalam diri anak dan akan berpengaruh pada potensi yang diperoleh.

Rasa percaya diri merupakan syarat utama untuk melanjutkan proses kegiatan belajar, kurang percaya diri akan menghambat pembelajaran selanjutnya. Tugas guru atau pembimbing adalah membantu anak yang sedang mengalami masalah, dalam konteks penelitian adalah membantu anak dalam upaya meningkatkan rasa percaya diri.

Salah satu upaya untuk meningkatkan rasa percaya diri pada anak melalui terapi bermain. Terapi bermain dipilih sebagai sesuatu metode yang tepat karena mempunyai beberapa keunggulan dalam memecahkan suatu permasalahan yang dihadapi oleh anak. Menurut Sutton Smith (dalam Elizabeth B. Hurlock, 1978), "Bermain bagi anak terdiri atas empat model dasar yang membuat kita mengetahui tentang dunia meniru, eksplorasi, menguji, dan membangun”. Sepanjang masa kanak-kanak, bermain sangat mempengaruhi penyesuaian pribadi dan sosial anak. Dengan bermain bersama anak lain, anak belajar membentuk hubungan sosial, bagaimana menghadapi dan memecahkan masalah yang timbul dalam hubungan tersebut.

Menurut Thantaway (2005), mengatakan bahwa percaya diri adalah kondisi mental atau psikologis diri seseorang yang memberi keyakinan kuat pada dirinya untuk berbuat atau melakukan sesuatu tindakan. Orang yang tidak percaya diri memiliki konsep diri negatif, kurang percaya pada kemampuannya, karena itu sering menutup diri.

Ratna Megawangi (2009) mengatakan bahwa, rasa percaya diri adalah bagaimana kita merasa dan melihat diri kita sendiri. Percaya diri juga yakin akan anggapan orang tentang diri kita. Percaya diri anak akan tumbuh kuat apabila orang tua dapat menumbuhkan perasaan "saya disayang dan diterima" (feeling lovable), dan "saya mempunyai kemampuan" dalam diri anak.

Rasa percaya diri (self confidence) menurut The American Heritage Dictionary (dalam Wishnubroto, 2005) didefinisikan sebagai "consciousness of one's own person and abilities" (kesadaran akan kekuatan dan kemampuan diri 
sendiri). Webster's New World Dictionary (dalam John Fereira, 2005) mendefinisikannya sebagai "reliance on one's own powers" (bergantung pada kekuatan diri sendiri). Berdasarkan pendapat di atas, maka kepercayaan diri adalah kondisi mental atau psikologis individu untuk dapat mengevaluasi keseluruhan dari dirinya sehingga memberi keyakinan kuat pada kemampuan dirinya untuk melakukan tindakan dalam mencapai berbagai tujuan di dalam hidupnya.

Menurut Hakim (2002), beberapa faktor-faktor yang mempengaruhi rasa percaya diri antara lain: 1) lingkungan keluarga, keadaan keluarga merupakan lingkungan hidup yang pertama dan utama dalam kehidupan setiap manusia. Lingkungan keluarga sangat mempengaruhi pembentukan awal rasa percaya diri pada seseorang; 2) pendidikan formal, sekolah bisa dikatakan sebagai lingkungan kedua bagi anak, dimana sekolah merupakan lingkungan yang paling berperan bagi anak setelah lingkungan keluarga di rumah. Sekolah memberikan ruang pada anak untuk mengekspresikan rasa percaya dirinya terhadap teman-teman sebayanya; 3) pendidikan non formal, salah satu modal utama untuk bisa menjadi seseorang dengan kepribadian yang penuh rasa percaya diri adalah memiliki kelebihan tertentu yang berarti bagi diri sendiri dan orang lain. Rasa percaya diri akan menjadi lebih mantap jika seseorang memiliki suatu kelebihan yang membuat orang lain merasa kagum. Kemampuan atau keterampilan dalam bidang tertentu bisa didapatkan melalui pendidikan non formal, misalnya: mengikuti kursus bahasa asing, bermain alat musik, seni vokal, pendidikan keagamaan, dan lain sebagainya.

Terdapat beberapa ciri anak yang mempunyai rasa percaya diri yang proporsional menurut Deny Hendrata (2011), yaitu: 1) percaya akan kompetensi/kemampuan diri, hingga tidak membutuhkan pujian, pengakuan, penerimaan, ataupun rasa hormat orang lain; 2) tidak terdorong untuk menunjukkan sikap konformis demi diterima oleh orang lain atau kelompok; 3) berani menerima dan menghadapi penolakan orang lain, berani menjadi diri sendiri; 4) mempunyai pengendalian diri yang baik (tidak moody dan emosi stabil); 5) memiliki internal locus of control (memandang keberhasilan atau 
kegagalan); 6) mempunyai rasa pandang yang positif terhadap diri sendiri, orang lain dan situasi diluar dirinya; 7) memiliki harapan yang realistik terhadap diri sendiri, sehingga ketika harapan itu tidak terwujud, ia tetap mampu melihat sisi positif dirinya dan situasi yang terjadi. Deny Hendrata (2011) juga mengemukakan mengenai ciri-ciri anak yang kurang memiliki rasa percaya diri, diantaranya meliputi: 1) berusaha menunjukkan sifat konformis, semata-mata demi mendapatkan pengakuan dan penerimaan kelompok; 2) menyimpan rasa takut/kekhawatiran terhadap penolakan; 3) sulit menerima realita diri (terlebih menerima kekurangan); 4) pesimis, mudah menilai segala sesuatu dari segi negatif; 5) takut gagal sehingga menghindari segala resiko dan tidak berani memasang target untuk berhasil; 6) selalu menempatkan dan memposisikan diri sebagai yang terakhir, karena menilai dirinya tidak mampu; 7) mempunyai external locus of control (mudah menyerah pada nasib, sangat tergantung pada keadaan dan pengakuan / penerimaan serta bantuan orang lain).

Hakim (2005) mengemukakan bahwa, berbagai kelemahan pribadi yang biasanya dialami dan sering menjadi sumber rasa tidak percaya diri antara lain: cacat atau kelainan fisik, buruk rupa, ekonomi lemah, status sosial, status perkawinan, sering gagal, kalah bersaing, kurang cerdas, pendidikan rendah, perbedaan lingkungan, tidak supel, tidak siap menghadapi situasi tertentu, sulit menyesuaikan diri, mudah cemas dan penakut, tidak terbiasa, mudah gugup, berbicara gagap, pendidikan keluarga yang kurang baik, sering menghindar, mudah menyerah, tidak bisa menarik simpati orang, serta kalah wibawa dengan orang lain.

Luxory (2001) menyatakan bahwa terdapat beberapa perasaan penting yang mengontrol emosi manusia dan membuatnya kehilangan percaya diri. Mula-mula disebabkan oleh perasaan cemas dan perasaan tidak tenang serta perasaanperasaan lain yang mengikutinya, seperti malas, kurang sabar, sulit, susah, atau rendah diri. Dengan perasaan tersebut, manusia menjadi ragu akan kemampuan dan dirinya. Kurang percaya diri juga dapat disebabkan oleh perasaan khawatir dan pikiran buruk. Perasaan inilah yang menimbulkan perasaan gelisah, tegang dan takut, sehingga menjadi kehilangan percaya diri. 
Hakim (2002) menjelaskan bahwa rasa percaya diri siswa di sekolah bisa dibangun melalui berbagai macam bentuk kegiatan, meliputi: memupuk keberanian untuk bertanya, peran guru/pendidik yang aktif bertanya pada siswa, melatih berdiskusi dan berdebat, mengerjakan soal di depan kelas, bersaing dalam mencapai prestasi belajar, aktif dalam kegiatan pertandingan olah raga, belajar berpidato, mengikuti kegiatan ekstrakurikuler, penerapan disiplin yang konsisten.

Gerungan (2011) menyebutkan terapi adalah mengubah diri sesuai dengan keadaan lingkungan, tetapi juga mengubah lingkungan sesuai dengan keadaan (keinginan diri). Menurut Blacher (dalam Latipun, 2006), tujuan terapi bermain pada dasarnya menekankan bahwa konseli berhasil mengembangkan sikap dan tingkah laku yang memuaskan bagi dirinya sendiri dan bagi lingkungannya, serta berhasil mengatur kehidupannya sendiri secara bertanggung jawab. Tujuan terapi berdasarkan masalah yang dihadapi anak dapat diklasifikasikan sebagai berikut: 1) mengubah perilaku yang salah penyesuaian, terapi ini diselenggarakan untuk membantu anak mengenali perilakunya yang salah dalam melakukan penyesuaian. Perilaku yang salah harus diketahui terlebih dahulu oleh anak, dipahami dan berikutnya dia harus secara sukarela mengubah perilakunya untuk mendapatkan cara kehidupan yang lebih baik; 2) belajar membuat keputusan, membuat keputusan bagi anak melalui proses belajar yaitu mulai belajar mengidentifikasi alternatif, memiliki alternatif, menetapkan alternatif serta memprediksi berbagai konsekuensi dari keputusannya. Konselor memberikan dorongan untuk berani membuat keputusan yang dibutuhkan dengan resiko yang sudah dipertimbangkan sebagai konsekuensi alamiah; 3) mencegah munculnya masalah, hal ini mengandung tiga pengertian yaitu: a) mencegah jangan sampai mengalami masalah di kemudian hari; b) mencegah jangan sampai masalah yang dialami bertambah berat atau berkepanjangan; dan c) mencegah jangan sampai masalah yang dihadapi berakibat gangguan yang menetap. Artinya tujuan dari terapi dapat dicapai secara bertahap dan pada akhirnya hendak mencapai tujuan akhirnya.

Pentingnya pengaruh bermain menurut Bergen (1998) mengungkapkan bahwa bermain dalam tatanan sekolah dapat digambarkan sebagai suatu rentang rangkaian kesatuan yang berujung pada bermain bebas, bermain dengan 
bimbingan dan berakhir pada bermain dengan diarahkan. Dalam bermain bebas dapat didefinisikan sebagai suatu kegiatan bermain dimana anak mendapat kesempatan melakukan berbagai pilihan alat dan mereka dapat memilih bagaimana menggunakan alat-alat tersebut. Kegiatan bermain dengan bimbingan, guru memilih alat permainan dan diharapkan anak-anak dapat memilih guna menemukan suatu konsep tertentu (besar atau kecil), maka guru akan menyediakan sejumlah mainan yang dapat diklasifikasikan dalam kelompok yang berukuran besar atau yang kecil. Dalam bermain yang diarahkan guru mengajarkan bagaimana cara menyelesaikan suatu tugas yang khusus. Menyanyikan suatu lagu, bersama bermain jari dan bermain dalam lingkaran adalah contoh dari bermain yang diarahkan.

Menurut Papalia (1995), bahwa anak berkembang dengan cara bermain. Dunia anak-anak adalah dunia bermain. Dengan bermain anak-anak menggunakan otot tubuhnya, menstimulasi indera-indera tubuhnya, mengeksplorasi dunia sekitarnya, menemukan seperti apa lingkungan yang ia tinggali dan menemukan seperti apa diri mereka sendiri. Dengan bermain, anak-anak menemukan dan mempelajari hal-hal atau keahlian baru dan belajar (learn) kapan harus menggunakan keahlian tersebut, serta memuaskan apa yang menjadi kebutuhan nya (need). Lewat bermain, fisik anak terlatih, kemampuan kognitif dan kemampuan berinteraksi dengan orang lain akan berkembang.

Fungsi dari kegiatan bermain adalah untuk mengembangkan seluruh potensi yang dimiliki oleh anak melalui penemuan-penemuan yang tidak disengaja. Kegiatan bermain dalam proses kegiatan pembelajaran dapat dilakukan di dalam dan di luar ruangan yang disesuaikan dengan kebutuhan dan tujuan kegiatan pengembangan.

Diharapkan dengan bermain anak dapat mengeksplorasi alternatif cara-cara berpikir dan bertingkah laku tanpa ketakutan akan kritik, penghinaan, atau penolakan. Inti dari tujuan bermain adalah meningkatkan rasa percaya diri anak.

Dalam bermain, menurut Kasihani (2008), memiliki 6 ciri, yaitu: 1) anak harus saling berinteraksi; 2) anak harus memahami aturan yang ada dalam permainan tersebut; 3) dalam bermain memiliki tujuan yang jelas; 4) konteks 
kegiatannya jelas; 5) anak harus terlibat secara aktif, 6) anak mendapat aturan khusus dalam bermain.

Rasa percaya diri anak dapat mempengaruhi perkembangan pendidikan selanjutnya. Anak yang sehat, cerdas, dan berkembang adalah anak yang mempunyai rasa percaya diri.

Dari uraian di atas cukup jelas bahwa rasa percaya diri sangatlah penting karena dengan mempunyai rasa percaya diri anak akan mampu mengembangkan potensi-potensi yang ada dalam diri anak, sehingga bisa menyesuaikan diri dengan baik serta menjadi pribadi yang mandiri melalui terapi bermain.

Melalui terapi bermain diharapkan rasa percaya diri anak dapat meningkat sehingga anak dapat belajar dengan baik dan memudahkan guru atau pembimbing dalam memberikan bimbingan. Berdasarkan uraian di atas, maka peneliti tertarik untuk melakukan penelitian dengan judul "Meningkatkan Rasa Percaya Diri Anak Melalui Terapi Bermain di Taman Kanak-kanak Kasih Ibunda, Kota Kediri”. Perumusan masalah dalam penelitian ini: apakah terapi bermain dapat meningkatkan rasa percaya diri anak TK Kasih Ibunda Kota Kediri.

\section{Metode}

Penelitian ini dilakukan di Taman Kanak-kanak Kasih Ibunda Kota Kediri. Sumber data diperoleh melalui seluruh anak TK Kasih Ibunda, dengan jumlah siswa 23 anak. Di TK Kasih Ibunda ini telah terdapat berbagai alat permainan dan buku-buku cerita atau dongeng sebagai penunjang kegiatan bermain dan belajar anak-anak. Berdasarkan pengamatan awal, diketahui bahwa rasa percaya diri anak masih rendah. Untuk itu, perlu dilakukan upaya peningkatan rasa percaya diri anak. Salah satunya adalah melalui penerapan terapi bermain dalam menyampaikan kegiatan bermain dan belajar pada anak. Materi bimbingan yang disampaikan kepada anak berkaitan dengan peningkatan rasa percaya diri anak. Adapun penyampaian layanan kegiatan bimbingan yang digunakan adalah melalui terapi bermain.

Pengumpulan data dalam penelitian ini menggunakan: 1) pengamatan atau observasi, digunakan untuk mengumpulkan data-data tentang sikap dan tingkah 
laku anak, khususnya dalam hal rasa percaya diri anak, baik sebelum maupun setelah penerapan terapi bermain untuk pembimbingan kegiatan bermain dan belajar anak; 2) wawancara, dilakukan antara peneliti dengan guru pembimbing untuk melakukan crosscheck antara fakta yang ditemukan di lapangan dengan data-data yang berkaitan dengan peningkatan rasa percaya diri anak; 3) terapi bermain, digunakan untuk merangsang anak agar lebih berani, aktif, dan kreatif dalam bermain, baik pada penggunaan alat-alat permainan yang disediakan pihak sekolah maupun pada saat berinteraksi dengan teman-temannya.

Metode yang digunakan dalam penelitian adalah metode penelitian tindakan kelas (PTK). Penelitian Tindakan Kelas (PTK) adalah penelitian tindakan (action research) yang dilakukan dengan tujuan memperbaiki mutu praktik pembelajaran di kelas. PTK berfokus pada kelas atau pada proses belajar mengajar yang terjadi di kelas, bukan pada input kelas (silabus, materi, dan lain-lain) ataupun output (hasil belajar). PTK harus tertuju atau mengenai hal-hal yang terjadi di dalam kelas (Suhardjono, 2006).

Berkaitan dengan metode yang digunakan dalam penelitian ini, maka analisis data yang digunakan adalah analisis deskriptif kualitatif. Penelitian dengan analisis deskriptif kualitatif merupakan suatu penelitian yang berusaha mengumpulkan, menyusun, menganalisis, dan menginterpretasikan data, atau menafsirkan arti kata yang berhubungan dengan masalah (Surachmat, 1990). Menurut Moleong (1998), penelitian kualitatif merupakan prosedur penelitian yang menghasilkan data deskriptif berupa kata-kata tertulis atau lisan tentang orang-orang dan perilaku yang diamati.

Pada penelitian ini, analisis deskriptif kualitatif digunakan untuk melakukan uraian atau penggambaran proses pembimbingan kegiatan anak untuk meningkatkan rasa percaya diri anak di TK Kasih Ibunda dengan terapi bermain, kemudian direfleksikan dan dianalisis. Jika rasa percaya diri anak belum mencapai tingkat keberhasilan, dilakukan tindakan pada siklus berikutnya.

Analisis data yang dilakukan dengan menggunakan pedoman bahwa rasa percaya diri anak meningkat jika selama pembimbingan kegiatan anak dengan 
menggunakan terapi bermain terdapat perubahan-perubahan dalam diri anak sesuai dengan indikator-indikator yang telah ditetapkan.

Adapun indikator-indikator rasa percaya diri anak yang digunakan dalam penelitian ini meliputi:

1. Anak aktif menggunakan seluruh alat permainan yang disediakan pihak sekolah.

2. Anak berinteraksi dengan teman pada saat bermain.

3. Anak mampu menggunakan berbagai alat permainan yang disediakan dan cenderung tidak hanya menggunakan salah satu alat permainan saja.

4. Anak berani menyampaikan pendapat jika mengalami kesulitan dalam bermain, berani bertanya kepada guru.

5. Anak mampu berkreasi dalam menggunakan alat-alat permainan edukatif, misalnya puzzle, balok huruf, dan sebagainya tanpa harus mendapat penjelasan dari guru.

Penilaian pengembangan rasa percaya diri anak dilakukan dengan memberi tanda pada lembar pedoman pengamatan setiap siklus sebagai berikut.

(-) : : anak belum mencapai indikator rasa percaya diri.

( $\sqrt{ }) \quad$ : anak telah mencapai indikator rasa percaya diri.

Setelah dilakukan pengamatan terhadap pencapaian indikator-indikator penelitian, dilakukan penghitungan persentase pencapaian indikator. Adapun perhitungan persentase yang digunakan adalah dengan rumus sebagai berikut.

$$
\mathrm{P}=\frac{\mathrm{F}}{\mathrm{N}} \mathrm{X} 100 \% \quad \text { (Agung Purwoko, 2001:103) }
$$

keterangan:

$\mathrm{P}=$ Persentase indicator rasa percaya diri anak

$\mathrm{F}$ = Jumlah nilai/skor indikator rasa percaya diri anak

$\mathrm{N}=$ Jumlah skor/indikator rasa percaya diri anak maksimum. 
Prosentase $=\frac{\text { Jumlah anak yang mencapai indikator rasa percaya diri }}{\text { Jumlah seluruh anak }} \times 100 \%$

(Agung Purwoko, 2001:103)

Dalam mendeskripsikan rasa percaya diri anak, interval criteria peningkatan rasa percaya diri anak ditentukan dengan cara sebagai berikut.

a. Persentase skor maksimum $=(5: 5) \times 100 \%=100 \%$

b. Persentase skor minimum $=(0: 5) \times 100 \%=0 \%$

c. Rentang persentase skor $=100 \%-0 \%=100 \%$

d. Banyaknya kriteria = (sangat tinggi, tinggi, sedang, rendah)

e. Panjang kelas interval = rentang : banyak criteria

$=100 \%: 4$

$=25 \%$

Berdasarkan panjang kelas interval tersebut maka kriteria rasa percaya diri anak dapat disusun sebagai berikut.

$76 \%-100 \%$ : sangat tinggi

$51 \%-75 \%$ : tinggi

$26 \%-50 \%$ : sedang

$0 \%-25 \% \quad$ : rendah

\section{Skenario Tindakan}

Penelitian ini menggunakan desain penelitian tindakan kelas. Penentuan rancangan penelitian didasarkan pada tujuan peneliti, yaitu mengembangkan peningkatan rasa percaya diri anak. Berdasarkan tujuan penelitian tersebut, disusun skenario tindakan yang meliputi hal-hal sebagai berikut:

1. Anak diberi penjelasan tentang berbagai alat bermain dan jenis-jenis permainan yang ada di TK, yang dapat digunakan oleh anak.

2. Guru/pembimbing mengenalkan konsep kegiatan anak dengan terapi bermain, baik dengan alat permainan maupun tanpa alat permainan. 
3. Guru/pembimbing bercerita tentang macam-macam permainan yang dapat memotivasi anak untuk bersifat kreatif dalam menggunakan jenis-jenis permainan yang dapat dilakukan dengan berbagai alat bermain yang ada.

4. Anak melaksanakan berbagai jenis permainan. Setiap anak diberi satu jenis alat bermain dan ditugaskan menggunakan alat permainan tersebut secara mandiri.

5. Pada saat kegiatan bermain, guru/pembimbing yang berperan sebagai observer, melakukan pengamatan dan mencatat rasa percaya diri pada masing-masing anak. Bila diperlukan, dilakukan pendampingan pada masing-masing anak.

Prosedur Penelitian

Penelitian ini menggunakan metode Penelitian Tindakan Kelas (PTK) dengan peningkatan pada unsur desain yang memungkinkan diperolehnya gambaran keefektifan penyampaian layanan pembimbingan kegiatan anak TK dengan terapi bermain yang dikembangkan sebagai metode pengembangan kreativitas bermain anak. Penelitian ini menggunakan metode penelitian tindakan kelas dengan 2 siklus, pelaksanaan tiap siklus mengikuti skema sebagai berikut.

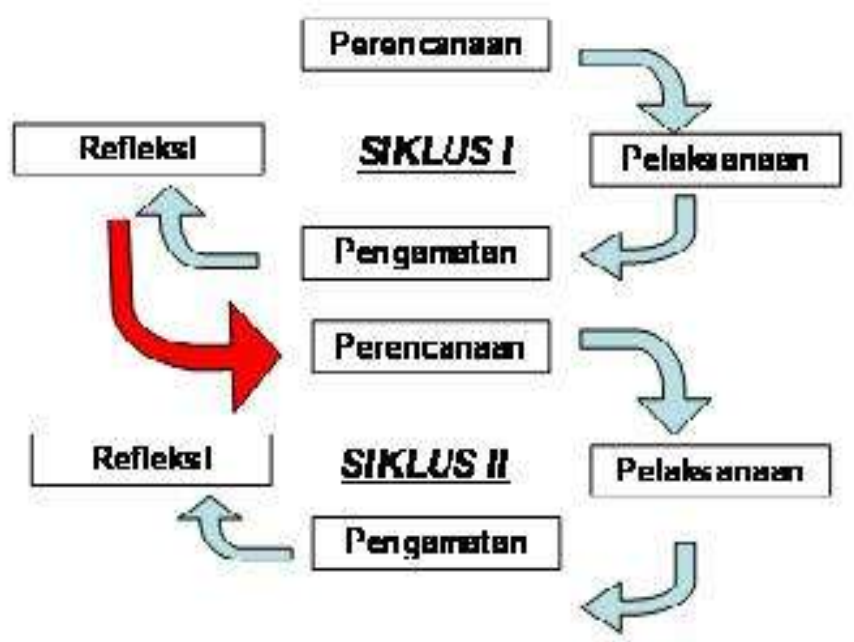

Gambar. Alur PTK

(Sumber: Suharsimi Arikunto 2002) 
Rencana penyampaian layanan pembimbingan kegiatan anak TK dengan menggunakan terapi bermain untuk meningkatkan rasa percaya diri anak di TK Kasih Ibunda Kota Kediri menggunakan prinsip penilaian tindakan kelas dimana PTK ini memiliki empat tahap, yaitu:

1. Perencanaan (planning)

2. Pelaksanaan/tindakan (acting)

3. Pengamatan (observing), dan

4. Refleksi (reflecting)

Instrumen yang digunakan dalam penelitian meliputi: 1) satuan kegiatan harian (SKH) pada materi pengembangan kreativitas bermain anak; 2) lembar pengamatan/observasi kreativitas bermain anak, yang disusun dalam bentuk lembar pedoman pengamatan kreativitas bermain anak dan diisi oleh observer pada saat pelaksanaan penyampaian layanan pembimbingan kegiatan anak dengan terapi bermain.

Hasil

Penelitian ini dilakukan melalui dua siklus, siklus pertama dan siklus kedua. Pelaksanaan kegiatan pada siklus pertama, masih terdapat kekurangan sehingga perlu adanya perbaikan dan bimbingan kepada anak yang tidak mengalami perubahan pada siklus berikutnya. Agar semua kekurangan dapat teratasi dan anak dapat mengalami peningkatan dalam hal mengatasi rasa percaya diri anak.

Dari hasil penelitian yang dimulai dari observasi awal kemudian siklus I, sampai siklus II diperoleh hasil peningkatan dalam hal percaya diri anak. Hasil penelitian menunjukkan adanya peningkatan di setiap siklusnya. Hal tersebut dapat dilihat pada tabel dan grafik gambar berikut: 
Tabel. Hasil observasi

\begin{tabular}{|c|c|c|c|c|c|}
\hline \multirow{2}{*}{ No } & \multirow{2}{*}{ Indikator } & \multicolumn{2}{|c|}{ Siklus I } & \multicolumn{2}{|c|}{ Siklus II } \\
\hline & & Jumlah & $\%$ & Jumlah & $\%$ \\
\hline 1. & $\begin{array}{l}\text { Anak dengan penuh rasa percaya diri } \\
\text { menggunakan alat permainan yang } \\
\text { disediakan pihak sekolah. }\end{array}$ & 5 & 25 & 17 & 85 \\
\hline 2. & $\begin{array}{l}\text { Anak berinteraksi dengan teman } \\
\text { pada saat bermain. }\end{array}$ & 7 & 35 & 19 & 95 \\
\hline 3. & $\begin{array}{l}\text { Anak mampu menggunakan berbagai } \\
\text { alat permainan yang disediakan dan } \\
\text { cenderung tidak hanya menggunakan } \\
\text { salah satu permainan saja. }\end{array}$ & 6 & 30 & 20 & 100 \\
\hline 4. & $\begin{array}{l}\text { Anak berani } \text { menyampaikan } \\
\text { pendapat dan jika mengalami } \\
\text { kesulitan dalam bermain, berani } \\
\text { bertanya kepada guru. }\end{array}$ & 5 & 25 & 19 & 95 \\
\hline 5. & $\begin{array}{l}\text { Anak mampu berkreasi dengan } \\
\text { menggunakan alat-alat permainan } \\
\text { edukatif }\end{array}$ & 8 & 40 & 15 & 80 \\
\hline & Jumlah / Rata-Rata & 31 & 50 & 70 & 80 \\
\hline
\end{tabular}

\section{Grafik Peningkatan Indikator Tiap Siklus}

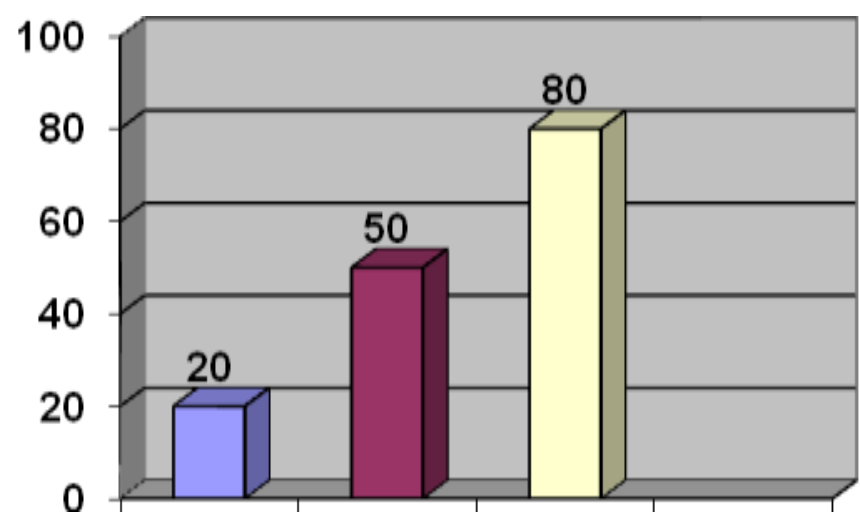

Observasi awal

Siklus 1

Siklus II 
Dari hasil analisis semua data yang diperoleh menunjukkan adanya peningkatan dalam hal mengatasi kurangnya rasa percaya diri anak yang dialami selama di sekolah, yang meliputi lima indikator diantaranya: 1) anak dengan penuh rasa percaya diri menggunakan alat permainan yang disediakan pihak sekolah; 2) anak berinteraksi dengan teman pada saat bermain; 3) anak mampu menggunakan berbagai alat permainan yang disediakan dan cenderung tidak hanya menggunakan salah satu permainan saja; 4) anak berani menyampaikan pendapat dan jika mengalami kesulitan dalam bermain, berani bertanya kepada guru; 5) anak mampu berkreasi dengan menggunakan alat-alat permainan edukatif, misalnya puzzle, balok huruf, dan sebagainya tanpa harus mendapat penjelasan dari guru.

Keberhasilan dalam penelitian ini dapat dilihat dari pencapaian rata rata dari tiap siklus, dan merupakan metode baru sehingga anak sangat antusias. Selain itu, dalam meningkatkan rasa percaya diri anak melalui terapi bermain mengalami peningkatan meskipun ada beberapa anak yang belum percaya diri. Dapat disimpulkan bahwa inti dari terapi bermain adalah bisa bereksplorasi sesuai dengan keinginannya. Terapi bermain dapat mengatasi masalah percaya diri anak di TK Kasih Ibunda Kota Kediri.

\section{Simpulan}

Berdasarkan hasil penelitian dapat disimpulkan bahwa, penerapan terapi bermain dapat meningkatkan rasa percaya diri anak di TK Kasih Ibunda Kota Kediri.

Agar proses belajar mengajar lebih baik dan lebih memberikan hasil yang optimal bagi siswa, maka disampaikan saran sebagai berikut: 1) bagi pihak sekolah, harus bersifat arif dan bijaksana dalam memberikan metode pembelajaran yang sesuai dengan perkembangan anak, sehingga anak berkembang dan memiliki rasa percaya diri; 2) bagi guru, perlu memberi dukungan moral supaya anak memiliki konsep diri/kepercayaan yang positif sehingga meningkatkan prestasi anak; 3) bagi orang tua, dibutuhkan peran positif dari orang tua dalam mendampingi anak sesuai dengan kemampuan yang dimiliki oleh anak; 
serta orang tua perlu membina hubungan yang baik dengan anak sehingga menimbulkan rasa percaya diri anak; 4) bagi peneliti lain, agar menemukan metode lain yang lebih relevan dalam peningkatan rasa percaya diri anak.

\section{DAFTAR PUSTAKA}

Erman Emti Prayitno. 2004. Dasar-Dasar Bimbingan Konseling. Jakarta:PT. Rineka Cipta.

Golman, Daniel. 2001. Kecerdasan Emosi Untuk Mencapai Puncak Prestasi. Jakarta:PT. Gramedia.

Hendrata, Deni. 2011. Karakteristik Percaya Diri. http://Deny_Hendrata.wordpress.com

I Wayan Dasna. 2008. Penelitian Tindakan Kelas dan Penulisan Karya Ilmiah. Malang:Depdiknas UNM PSG Rayon 15.

Ibadullah Malawi. 2007. Penelitian Pendidikan, Diklat Mata Kuliah Penelitian Pendidikan. Tim Dosen IKIP PGRI Madiun.

Latipun. 2006. Psikologi Konseling. Malang: UMM Press

Ratna Megawangi. 2009. Menyemai Benih Karakter. Depok: Indonesia Heritage Foundation

Sri Habsari. 2005. Bimbingan dan Konseling SMA Untuk Kelas XI. Jakarta:---

Suharsimi Arikunto. 2002. Prosedur Penelitian Suatu Pendekatan Praktek. Jakarta: PT. Rineka Cipta. 2006. Penelitian Tindakan Kelas. Jakarta: Bumi Aksara

Sumadi Suryabrata. 2004. Psikologi Pendidikan, Jakarta : PT Raja Grafindo Persada

Vitalis. 2006. Bimbingan Dan Konseling Di Institusi Pendidikan. Diktat Mata Kuliah Prodi BK IKIP PGRI Madiun. . 2008. Pengantar Konseling dan Penerapan Beberapa Teori Konseling. Madiun: IKIP PGRI Madiun

Wishnubroto Widarso. 2005. Sukses Membangun Rasa Percaya Diri. Jakarta: PT. Gramedia. 